\title{
Chemical, Starch Digestibility and Sensory Characteristics of Durum Wheat/Unripe Whole Banana Flour Blends for Spaghetti Formulation
}

\author{
Perla Osorio-Díaz ${ }^{*}$, José J. Islas-Hernández ${ }^{1}$, Edith Agama-Acevedo ${ }^{1}$, Sandra L. Rodríguez-Ambriz ${ }^{1}$, \\ María E. Sánchez-Pardo², Luis A. Bello-Pérez ${ }^{1}$
}

${ }^{1}$ Center for Development of Biotic Products, National Polytechnique Institute, Yautepec, México; ${ }^{2}$ National School of Biological Sciences, National Polytechnique Institute, México, D.F., México.

Email: *posorio@ipn.mx

Received August 22 ${ }^{\text {nd }}, 2013$; revised September 22 ${ }^{\text {nd }}, 2013$; accepted September 30 ${ }^{\text {th }}, 2013$

Copyright (C) 2014 Perla Osorio-Díaz et al. This is an open access article distributed under the Creative Commons Attribution License, which permits unrestricted use, distribution, and reproduction in any medium, provided the original work is properly cited. In accordance of the Creative Commons Attribution License all Copyrights (C) 2014 are reserved for SCIRP and the owner of the intellectual property Perla Osorio-Díaz et al. All Copyright @ 2014 are guarded by law and by SCIRP as a guardian.

\section{ABSTRACT}

Excess weight and obesity are serious public health problems, which should be addressed through encouraging the consumption of foods with high amount of low digestible carbohydrates. The objective of this study was to put together spaghetti that blends unripe banana whole flour (UBWF) and durum wheat of different levels and to evaluate their chemical composition, starch digestibility and sensory characteristics. Spaghetti with $15 \%, 30 \%$, and $45 \%$ of UBWF and a control spaghetti $(100 \%$ durum wheat flour) were put together. The protein content decreased (10.42\% to $7.74 \%)$ as the UBWF level was increased in the composite, while the amount of ash $(0.87 \%$ to $1.54 \%$ ) and total starch $(70.24 \%$ to $73.71 \%)$ increased. Spaghetti with $15 \%$ and $45 \%$ of UBWF had similar available starch content. The addition of UBWF increased the resistant starch content from $1.98 \%$ to $10.91 \%$, and consequently the indigestible starch fraction $(14.00 \%$ to $27.29 \%)$. Spaghetti with $30 \%$ of UBWF had good consumer acceptability and was ranked higher than the control sample.

\section{KEYWORDS}

Starch; Digestibility; Banana; Spaghetti; Indigestible Fractio

\section{Introduction}

Excess weight and obesity are serious public health problems in Mexico [1]. The consumption of foods with high indigestible carbohydrate content is an alternative way to control weight and obesity problems because these foods have a low caloric content. Pasta is a very popular food, mainly because of its low lipid (no cholesterol) and sodium content, and slow digestion [2,3]. Pasta is traditionally put together with durum wheat flour (semolina) and water. Pasta is also commercially available with added food ingredients such as egg, spinach, tomato, herbs, tuber flours, and chocolate [4]. These ingredients give color and flavor to pasta, but they do not have an important nutritional effect [5]. Several studies have reported the

\footnotetext{
*Corresponding author.
}

addition of some food ingredients to pasta for the production of functional foods. Some examples are pasta with added legume flours, amaranth, lupinus, carrot, maize, cassava starch, or banana starch [6-8], and more recently the preparation of fiber-enriched pasta using different ingredients blended with wheat flour $[9,10]$. In order to add commercial value to the banana fruit, banana starch has been used in pasta as a functional ingredient due to its high resistance to digestion [11,12]. Unripe banana flour (UBF) prepared from the pulp has a high level of indigestible polysaccharides, dietary fiber and antioxidant compounds [13]. UBF has been used in bread [14] and spaghetti [15]; these products presented high indigestible carbohydrate content. The peel represents around 25\% $30 \%$ of the weight (wet basis) of the banana fruit and when UBF is produced, a large amount of peel is 
discarded, representing in some cases a significant environmental problem. On the other hand, whole banana fruit has been used to produce a fiber-enriched ingredient after acid treatment [16]. Whole banana fruit can be ground into flour (WBWF), which can potentially be used as an ingredient that has a high level of dietary fiber. We hypothesize that it is possible to produce and use UBWF as a functional ingredient to blend with durum wheat in the production of spaghetti without compromising the nutritional, cooking quality, and sensory features. Additionally, the integral use of banana fruit could be an economical and ecological alternative compared with the use of UBF. The aim of this study was to elaborate and evaluate the chemical composition, texture, carbohydrate digestibility and sensory evaluation of spaghetti containing different levels of UBWF.

\section{Materials and Methods}

\subsection{Unripe Banana Whole Flour (UBWF) Preparation}

Commercial unripe (green) banana (Musa paradisiaca L.) fruits were purchased from the local market in Cuautla, Morelos State, Mexico. Fruits were cleaned and brushed, the ends were removed; fruits were cut into $1-\mathrm{cm}$ slices and were immediately rinsed in citric acid solution $(0.3 \%$ $\mathrm{w} / \mathrm{v}$ ). The slices were dried at $50^{\circ} \mathrm{C}$ in an oven (Biotecnica del Bajio, Celaya, Guanajuato, Mexico), ground on a commercial grinder (Mapisa Internacional S.A de C.V., México, D.F.) to pass a US 50 sieve $(0.3 \mathrm{~mm})$, and stored at $25^{\circ} \mathrm{C}$ in sealed plastic containers for further analyses.

\subsection{Spaghetti Processing}

Formulations consisting of $100 \%$ durum wheat semolina (control) and mixtures of semolina:UBWF of 85:15, 70:30 and 55:45 were prepared for spaghetti processing. The homogenized blend was mixed with water $(50 \mathrm{~mL}$ of water for $100 \mathrm{~g}$ of flour) for 5 min to allow hydration. The dough was obtained, and extruded as spaghetti (1.5$\mathrm{mm}$ dia) using a commercial shop sized pasta maker (KitchenAid, Model KPRA, St. Joseph, MI. USA). The spaghettis were cut as they came out of the pasta roller and dried at $45^{\circ} \mathrm{C}$ for $4 \mathrm{~h}$ in a forced air oven. Spaghetti was prepared in duplicate for each formulation. Spaghettis $(3 \mathrm{~g})$ were cooked in boiling water $(100 \mathrm{~mL})$ until the white color in the pasta's central core disappeared, as evaluated after squeezing the spaghetti between two glass slides (66-50) [17]. Cooked spaghetti was frozen in liquid nitrogen, freeze dried, and ground to pass a $300 \mu \mathrm{m}$ sieve, using a commercial grinder (Mapisa Internacional S.A. de C.V., México, D.F.). The samples were stored at room temperature in sealed plastic containers for further analyses.

\subsection{Chemical Analysis}

Moisture content was determined by gravimetric heating $\left(130^{\circ} \mathrm{C} \pm 2^{\circ} \mathrm{C}\right.$ for $\left.2 \mathrm{~h}\right)$ using $2-3 \mathrm{~g}$ raw spaghetti sample. Ash, protein $(\mathrm{N} \times 5.85)$ and fat were assessed according to AACC methods $08-01,46-13$ and $30-25$, respectively [17]. All analyses were performed in triplicate.

\subsection{Determination of Cooking Properties}

\subsubsection{Cooking Loss}

Cooking water collected from each sample was evaporated until constant weight in an air oven at $105^{\circ} \mathrm{C}$. The residue was weighted and reported as percentage of original spaghetti sample according to approved methods (6650 cooking loss) [17].

\subsubsection{Cooking Yield}

Spaghetti strands (12.5 g) were cut into 5-cm long pieces, cooked in $200 \mathrm{~mL}$ boiling distilled water until their optimal cooking time was reached. Afterwards, they were drained and rinsed with $50 \mathrm{~mL}$ of distilled water at room temperature for $1 \mathrm{~min}$. The samples were weighed after reaching room temperature. Water absorption was determined as [(weight of cooked drained pasta - weight of raw pasta)/weight of raw pasta] $\times 100$.

\subsection{Cooked Spaghetti Textural Analysis}

Two batches of cooked pasta were prepared for each product. In each case, four sub-samples were evaluated by Texture Profile Analysis (TPA) using the Texture Analyzer (Stable Micro System, Godalming, UK) within 5 min after cooking. Different texture analyses were performed: spaghetti hardness, adhesiveness, cohesiveness, elasticity (or tensile strength), stickiness, and chewiness. For all measurements, the TA-XT2i was equipped with a 25-kg load cell. All samples were prepared and stored at room temperature until measurement, according to the approved AACC method (66-50 pasta cooking qualityfirmness test) [17].

\subsection{Starch Digestibility Tests}

Total starch (TS) was determined by the Goñi's method [18]. Resistant starch (RS) was measured by Goñi et al. method [18]. In brief, protein and digestible starch were removal with pepsin (P7012 (2500 - 3500 units/mg protein, Sigma Chemical Co., St. Louis, MO) incubation $\left(40^{\circ} \mathrm{C}, \mathrm{pH} 1.5,1 \mathrm{~h}\right)$ and $\alpha$-amylase (A3176 (10 - 30 units/mg solid, Sigma Chemical Co., St. Louis, MO) incubation $\left(37^{\circ} \mathrm{C}, \mathrm{pH} 6.9,16 \mathrm{~h}\right)$. The residue was treated with $2 \mathrm{M} \mathrm{KOH}$ and after the sample was incubated with amyloglucosidase (A-7255 (5000 units/g solid, Sigma Chemical Co., St. Louis, MO) $\left(60^{\circ} \mathrm{C}, \mathrm{pH} 4.75,45 \mathrm{~min}\right)$. 
Glucose was determined using glucose oxidase/peroxidase assay (Elitech Glucose PAP SL). RS was calculated as glucose $(\mathrm{mg}) \times 0.9$.

Digestible starch was calculated by difference between TS and RS.

\subsection{Indigestible Fraction}

Soluble (SIF) and insoluble (IIF) indigestible fractions were assessed using Saura-Calixto's method [19]. In brief, $300 \mathrm{mg}$ of sample was added $0.2 \mathrm{~mL}$ of a pepsin solution containing $300 \mathrm{mg}$ of pepsin/mL of $\mathrm{HCl}-\mathrm{KCl}$ $(0.05 \mathrm{M} \mathrm{HCl}$ and $0.03 \mathrm{M} \mathrm{KCl}$, respectively) buffer, $\mathrm{pH}$ 1.5. Samples were incubated for $1 \mathrm{~h}$ at $40^{\circ} \mathrm{C}$ in a water bath with constant shaking. Then, $9 \mathrm{~mL}$ of Tris-maleate buffer $(0.1 \mathrm{M}, \mathrm{pH} 6.9)$ was added and the $\mathrm{pH}$ checked. $\alpha$-amylase $1 \mathrm{~mL}$ of a $120 \mathrm{mg} / \mathrm{mL}$ solution in Tris-maleate buffer was added, and the samples were incubated in a water bath at $37^{\circ} \mathrm{C}$ for $16 \mathrm{~h}$ with constant shaking. Samples were centrifuged (15 min, $3000 \mathrm{~g}$ ) and supernatants removed. Residues were washed twice with 10 $\mathrm{mL}$ of distilled water and all supernatants combined. The residues were dried overnight at $105^{\circ} \mathrm{C}$ and quantified gravimetrically as the IIF. Supernatants were transferred into dialysis tubes (12,000 - 14,000 MWCO; Dialysis Tubing Visking, Medicell International Ltd., London, U.K.), and dialyzed against water for $48 \mathrm{~h}$ at $25^{\circ} \mathrm{C}$ (water flow $7 \mathrm{~L} / \mathrm{h}$ ). Dialisates were then hydrolyzed with $1 M$ sulfuric acid at $100^{\circ} \mathrm{C}$ for $90 \mathrm{~min}$, and the SIF was measured with dinitrosalicylic acid [20].

\subsection{Preference Test}

For preference assessment, spaghettis were served hot on coded plates. Consumers were asked to assess their degree of liking by paper ballot using the ranking preference test on a 9-point hedonic rating scale, where $9=$ like extremely and 1 = dislike extremely.

Fifty consumers were briefed on evaluation protocol and then proceed to randomly evaluate the coded samples. A total of 50 Mexican consumers (33 female, 17 male, age range 17 - 57 years) of spaghetti were sampled from CEPROBI-IPN personnel, students and visitors. Consumers were randomly approached and after obtaining demographic details, they were asked to perform the tasting and express their liking by using a hedonic scale (Table 1).

The stimuli were placed on separate plastic trays and labeled with three digit random numbers. The order of presentation of the stimuli was counterbalanced over consumers. Each consumer tasted approximately $1 \mathrm{~g}$ of each sample. Rinses were taken before tasting and swallowing the samples. Consumers responded by filling in a response sheet.
Table 1. Nine-point hedonic scale ${ }^{\mathrm{a}}$ used in the preference test, with the corresponding Spanish translation.

\begin{tabular}{cc}
\hline English & Spanish \\
\hline Like extremely & Gusta muchisimo \\
Like very much & Gusta mucho \\
Like moderately & Gusta moderadamente \\
Like slightly & Gusta poco \\
Neither like nor dislike & Ni gusta ni disgusta \\
Dislike slightly & Disgusta poco \\
Dislike moderately & Disgusta moderadamente \\
Dislike very much & Disgusta mucho \\
\hline
\end{tabular}

${ }^{\mathrm{a}}$ Hedonic scale: 1 = dislike extremely, 5 = neither like nor dislike, 9 = like extremely.

\subsection{Statistical Analysis}

Results are presented as mean \pm SEM (standard error of mean) of three separate determinations. A commercial software programme (Sigma Stat ver. 2.03, Jandel Corporation, San Rafael, CA) was used to evaluate by one-way analysis of variance (ANOVA) to identify significant differences in the means of measured parameters. Statistically significant differences $(\mathrm{P}<0.05)$ among means were evaluated using the Tukey multiple comparison procedure.

\section{Results and Discussion}

\subsection{Chemical Composition}

The chemical compositions of the composite spaghettis of unripe banana whole flour (UBWF) and durum wheat, along with the control sample, are shown in Table 2. The protein content in the composite spaghetti decreased as the level of the UBWF flour was increased in the blend. However, no statistical difference $(\mathrm{P}<0.05)$ in the protein content was found between the control sample and the spaghetti with $15 \%$ of UBWF. This pattern is related to the effect of dilution because the pulp of unripe banana flour (UBF) [15] as well as that prepared with the whole fruit [16] has a low protein content. Composite spaghettis with UBWF presented a lower protein content than spaghettis with UBF [15] because in the former a higher amount of non-starch polysaccharides is present as a result of the peel. Spaghetti with added banana starch showed a similar pattern because the composites with $5 \%$ and $20 \%$ of banana starch had $10.6 \%$ and $9.0 \%$ of protein content, respectively [8]. The ash content increased as the amount of UBWF was increased in the spaghetti. This effect was due to the higher ash content in the UBWF than in the durum wheat. A similar pattern was reported in spaghetti with $15 \%$ of UBF (1.43\%) and spaghetti with $45 \%$ of UBF (1.83\%) [15]. However, the composite spaghetti with UBWF had a lower ash content 
Table 2. Chemical composition of spaghetti with unripe banana whole flour $(\mathrm{g} / \mathbf{1 0 0 g})$.

\begin{tabular}{ccccc}
\hline Sample & Protein & Lipids & Ash & Total Starch \\
\hline Control & $10.42 \pm 0.90^{\mathrm{a}}$ & $0.54 \pm 0.15^{\mathrm{a}}$ & $0.87 \pm 0.04^{\mathrm{d}}$ & $70.24 \pm 2.36^{\mathrm{b}}$ \\
$15 \%$ & $10.00 \pm 0.45^{\mathrm{a}}$ & $0.53 \pm 0.16^{\mathrm{a}}$ & $0.98 \pm 0.06^{\mathrm{c}}$ & $71.44 \pm 1.84^{\mathrm{a}, \mathrm{b}}$ \\
$30 \%$ & $8.87 \pm 0.25^{\mathrm{b}}$ & $0.48 \pm 0.10^{\mathrm{a}}$ & $1.30 \pm 0.03^{\mathrm{b}}$ & $71.34 \pm 2.60^{\mathrm{b}}$ \\
$45 \%$ & $7.74 \pm 0.32^{\mathrm{c}}$ & $0.40 \pm 0.15^{\mathrm{a}}$ & $1.64 \pm 0.04^{\mathrm{a}}$ & $73.71 \pm 0.79^{\mathrm{a}}$ \\
\hline
\end{tabular}

${ }^{\mathrm{a}}$ Values is mean \pm SEM. Different letters in a column indicate significant difference ( $\mathrm{P}<0.05$, Tukey's test).

than its counterpart with UBF (Table 2). The fat content in the spaghetti did not change with the addition of UBWF; this pattern is in agreement with the fat content in spaghetti with UBF [15] and banana starch [8].

A slight increase, but significant $(\mathrm{P}<0.05)$, in total starch (TS) content was assessed in the spaghetti with the highest UBWF level. Similar results were reported using UBF and durum wheat flour [15]. Conversely, a higher TS level was reported in spaghetti with $100 \%$ durum wheat flour $(74.1 \%$ and $73.9 \%$ ) [21-23]. This pattern is due to the higher total starch content in unripe banana [15].

\subsection{Cooking Tests}

The cooking time decreased as the level of UBWF increased in the composite spaghetti (Table 3). The addition of non-gluten flours in the production of spaghetti dilute the gluten strength of the semolina, interrupting and weakening the overall structure of the spaghetti, facilitating the heat transfer during cooking and thus leading to faster cooking [6]. The control spaghetti as well as those with $15 \%$ and $30 \%$ of UBWF had similar cooking loss values (Table 3); the spaghetti with the highest UBWF level showed the highest cooking loss value. The control spaghetti had the lowest cooking loss value (4.94\%), a value that was lower than in spaghetti with $100 \%$ semolina: $6.40 \%-6.50 \%$ [24] and 6.50\% [8]. However, the lower cooking loss value $(0.93 \%)$ was determined in the spaghetti with $100 \%$ semolina [25]. These values show that wheat durum varieties and the process conditions for spaghetti preparation play an important role in the cooking loss. For spaghetti made with $100 \%$ semolina, the cooking loss of $\leq 8 \%$ is considered acceptable for good quality pasta [26]. In this sense, the spaghetti types containing different levels of UBWF were within the expected values of cooking loss, and they could be considered as spaghetti of good cooking quality. A similar pattern in the cooking loss value was reported in the composite spaghetti because the control sample presented a lower cooking loss value than the composite spaghetti types. This may allow for a leaching out of more solids from the pasta into the cooking water [6]. Bahnassey \& Khan [27] reported that the cooked weight of spaghetti
Table 3. Determination of cooking properties of spaghetti with unripe banana whole flour.

\begin{tabular}{cccc}
\hline Sample & Cooking time (min) & Cooking loss (\%) & Cooking yield (\%) \\
\hline Control & $8.5 \pm 0.19^{\mathrm{a}}$ & $4.94 \pm 0.37^{\mathrm{b}}$ & $274.1 \pm 1.58^{\mathrm{a}}$ \\
$15 \%$ & $6.0 \pm 0.11^{\mathrm{b}}$ & $5.23 \pm 0.50^{\mathrm{b}}$ & $269.8 \pm 3.50^{\mathrm{a}}$ \\
$30 \%$ & $5.1 \pm 0.12^{\mathrm{c}}$ & $5.51 \pm 0.48^{\mathrm{a}, \mathrm{b}}$ & $257.1 \pm 2.50^{\mathrm{b}}$ \\
$45 \%$ & $4.0 \pm 0.15^{\mathrm{d}}$ & $6.42 \pm 0.60^{\mathrm{a}}$ & $248.0 \pm 2.90^{\mathrm{c}}$ \\
\hline
\end{tabular}

${ }^{\mathrm{a}}$ Values is mean \pm SEM. Different letters in a column indicate significant difference $(\mathrm{P}<0.05)$.

containing navy beans, pinto beans, and lentil flours decreased compared with the control sample (100\% durum wheat); however, the cooking loss and firmness of these products increased. In general, water absorption in the cooked spaghetti decreased when UBWF was increased in the composite spaghetti (Table 3). However, the control spaghetti and that with $15 \%$ of UBWF were not statistically different; both types of spaghetti increased 3.7 times in weight, while those with $30 \%$ and $45 \%$ of UBWF increased 3.6 and 3.5 times in weight, respectively. When UBF from the pulp was added to spaghetti, lower water absorption values were obtained; the control spaghetti increased 1.7 times in weight, while the spaghetti with the highest UBF level (45\%) increased 1.5 times in weight [15].

During spaghetti cooking some soluble components go into the cooking water, reducing the amount of solids such as starch, non-starch polysaccharides, and proteins. Therefore, the water amount that can be retained in the matrix of the spaghetti is low [6]. These results are in agreement with the higher cooking loss in the formulation with higher UBWF levels.

\subsection{Cooked Spaghetti Texture Analysis}

Table 4 shows the results of the texture analysis for the control sample and the composite spaghettis with UBWF. Texture plays an important role in determining the final acceptance by the consumer, and it is one of the predominant criteria for assessing pasta quality $[28,29]$. The control sample had the lowest hardness value, while no statistical difference was observed between the control spaghetti and the types with UBWF. The addition of UBWF produced an increase in the adhesiveness of the spaghetti, and this effect was higher as the level of UBWF was increased in the spaghetti. The data on adhesiveness is a measure of the force between the pasta and the contact surface [30], which is a function of the components in the spaghetti. In general, the elasticity and chewiness did not change with the addition of UBWF, although an appreciable increase in the chewiness was observed with the addition of UBWF to the blend. The addition of UBF presented similar texture values for hardness, adhesiveness, and chewiness [31], but higher values of elasticity 
Table 4. Texture attributes of cooked spaghetti with unripe banana whole flour.

\begin{tabular}{cccccc}
\hline Sample & Hardness & Adhesiveness & Elasticity & Stickiness & Chewiness \\
\hline Control & $3.84 \pm 0.40^{\mathrm{a}}$ & $1.25 \pm 0.05^{\mathrm{d}}$ & $1.10 \pm 0.05^{\mathrm{c}}$ & $5.25 \pm 0.08^{\mathrm{a}}$ & $3.71 \pm 0.30^{\mathrm{b}}$ \\
$15 \%$ & $4.15 \pm 0.20^{\mathrm{a}}$ & $1.39 \pm 0.03^{\mathrm{c}}$ & $1.16 \pm 0.03^{\mathrm{b}, \mathrm{c}}$ & $4.95 \pm 0.14^{\mathrm{b}}$ & $6.11 \pm 0.50^{\mathrm{a}}$ \\
$30 \%$ & $4.10 \pm 0.50^{\mathrm{a}}$ & $1.51 \pm 0.01^{\mathrm{b}}$ & $1.24 \pm 0.06^{\mathrm{b}}$ & $4.53 \pm 0.20^{\mathrm{c}}$ & $6.22 \pm 0.20^{\mathrm{a}}$ \\
$45 \%$ & $4.05 \pm 0.19^{\mathrm{a}}$ & $1.63 \pm 0.02^{\mathrm{a}}$ & $1.30 \pm 0.05^{\mathrm{a}}$ & $4.12 \pm 0.11^{\mathrm{d}}$ & $6.58 \pm 0.40^{\mathrm{a}}$ \\
\hline
\end{tabular}

${ }^{\mathrm{a}}$ Values is mean \pm SEM. Different letters in a column indicate significant difference $(\mathrm{P}<0.05$, Tukey's test).

were obtained for the types of spaghetti with UBWF. The presence of non-starch polysaccharides in the peel could be responsible for these results.

\subsection{Starch Digestibility}

The amount of digestible starch (DS) in the spaghetti decreased significantly ( $\mathrm{P}<0.05$ ) with the addition of UBWF (Table 5) compared with the control sample, but no difference in the DS value was found in the three composite spaghettis. A similar pattern was observed for the composite spaghettis made of a blend of UBF:durum wheat with $15 \%$ and $30 \%$ of UBF, where the DS content was similar to the control sample [15]. In another study, spaghetti with chickpea flour showed lower DS content than the control spaghetti [21].

A significant $(\mathrm{P}<0.05)$ increase in resistant starch $(\mathrm{RS})$ content was obtained in the spaghetti with the addition of UBWF, reaching $10.91 \%$ of RS content in the sample with 45\% UBWF (Table 5). Spaghetti with $15 \%$ of UBWF presented $8.66 \%$ of RS, which represented an increase in RS level of approximately $400 \%$ compared to the control spaghetti. The spaghetti with UBWF had a higher RS content than the spaghetti with UBF at the same level of substitution. For example, the spaghetti with $15 \%$ of UBF presented $2.84 \%$ of RS content [15], and its counterpart with UBWF had an RS content of 8.66\%. The difference can be explained by the UBWF including the peel. Also, more non-starch polysaccharides are present, decreasing the accessibility of the enzyme at substrate (starch). It has been reported that unripe banana flour is the natural food ingredient with the highest RS content, between 57.2\% and 47.3\% [11]. Another study reported that spaghetti with banana starch reached up to $10.33 \%$ of RS content in the composite, with $20 \%$ of banana starch and $80 \%$ durum wheat [8]. Additionally, noodles with banana starch at different concentrations had RS levels between 3.0\% and 4.6\% [32]. Nowadays, there is a growing interest in the nutritional significance of starch digestibility and dietary fiber due to the excess weight and obesity problems worldwide [33]. Therefore, the results obtained in this study on the potential use of UBWF as a food ingredient to reduce starch digestibility and increase dietary fiber (as RS) in the diet may be of importance for the food industry.

\subsection{Indigestible Fraction}

The indigestible fraction (IF) consists of those food ingredients that, being unavailable for digestion in the small intestine, pass into the colon where the fermenta- tive microflora may further process them. The soluble indigestible fraction (SIF) comprises monosaccharides, disaccharides, and oligosaccharides, while the insoluble indigestible fraction (IIF) includes RS, indigestible protein, polyphenols, and non-starch polysaccharides (cellulose, hemicelluloses and lignin) [19]. Both fractions increased as the UBWF level in the composite spaghetti were increased too (Table 5). A similar pattern was reported for spaghetti with chickpea flour added [21]. Another study reported that spaghetti with UBF added showed a similar pattern for the IIF (26.18\% IFF at the highest UBF addition of $45 \%$ ) as that observed in the present study (21.03\%), but not for the SIF value [15].

\subsection{Preference Test}

Table 6 presents the acceptability of spaghetti control and those types containing different levels of UBWF, using a 9 points hedonic scale.

The acceptability of the spaghetti containing $15 \%$ and $30 \%$ UBWF was similar, with values higher up to 6 (like slightly), indicating that there was a significant preference $(\mathrm{P}<0.05)$ for these two samples. The acceptability for the control spaghetti (100\% durum wheat flour) and that with the highest concentration of UBWF (45\%) was lower than for those samples containing $15 \%$ and $30 \%$ of UBWF. An acceptability study done on spaghetti prepared with different levels of UBF demonstrated that this parameter increased with the addition of tomato flavor, and the types of spaghetti with the highest UBF content (30\% and 45\%) had higher acceptability than the control sample and the sample with 15\% UBF [15].

\section{Conclusion}

Composite spaghetti with UBWF had a lower protein content, but a higher ash and starch content than the control sample. The cooking time was shorter and the cooking loss increased with the addition of UBWF. Some texture characteristics changed with the addition of UBWF. The resistant starch content increased when UBWF was 
Table 5. Digestible starch (DS), resistant starch (RS) and fraction indigestible (IF) of spaghetti with unripe banana whole Flour (g/100g).

\begin{tabular}{|c|c|c|c|c|c|}
\hline Sample & DS & RS & IIF & SIF & TIF \\
\hline Control & $68.26 \pm 0.69^{\mathrm{a}}$ & $1.98 \pm 0.02^{\mathrm{d}}$ & $10.95 \pm 0.22^{\mathrm{d}}$ & $3.05 \pm 0.10^{\mathrm{d}}$ & $14.00^{\mathrm{d}}$ \\
\hline $15 \%$ & $62.78 \pm 2.12^{b}$ & $8.66 \pm 0.51^{c}$ & $12.42 \pm 0.30^{c}$ & $3.51 \pm 0.25^{c}$ & $15.93^{c}$ \\
\hline $30 \%$ & $62.59 \pm 1.87^{\mathrm{b}}$ & $9.22 \pm 0.16^{\mathrm{b}}$ & $17.46 \pm 0.02^{\mathrm{b}}$ & $5.17 \pm 0.21^{b}$ & $22.63^{b}$ \\
\hline $45 \%$ & $63.01 \pm 1.77^{\mathrm{b}}$ & $10.91 \pm 1.13^{\mathrm{a}}$ & $21.03 \pm 0.91^{\mathrm{a}}$ & $6.26 \pm 0.27^{\mathrm{a}}$ & $27.29^{\mathrm{a}}$ \\
\hline
\end{tabular}

${ }^{a}$ Values is mean \pm SEM. Different letters in a column indicate significant differences $(\mathrm{P}<0.05)$. IIF: insoluble indigestible fraction; SIF: soluble indigestible fraction; TIF: total indigestible fraction.

Table 6. Sensory evaluation score of spaghetti with unripe banana whole flour.

\begin{tabular}{cc}
\hline Sample & Score hedonic scale \\
\hline Control & $5.84 \pm 0.23^{\mathrm{a}}$ \\
$15 \%$ & $6.02 \pm 0.18^{\mathrm{b}}$ \\
$30 \%$ & $6.06 \pm 0.24^{\mathrm{b}}$ \\
$45 \%$ & $5.90 \pm 0.23^{\mathrm{a}}$ \\
\hline
\end{tabular}

$\overline{{ }^{a} \text { Mean } \pm \text { SEM }(n=50) \text {. Mean with different letters indicate significant }}$ differences $(\mathrm{P}<0.05)$.

increased in the blend. A similar pattern was found in the indigestible fraction; an increase of approximately 100\% was determined in the spaghetti with $45 \%$ of UBWF compared with the control sample. The acceptability study demonstrated that consumers were favourable to spaghettis containing 15\% and 30\% UBWF. The results obtained in this study on the potential use of UBWF as a food ingredient to reduce starch digestibility and increase dietary fiber (as RS) in the diet should be important for the food industry. Additionally, the preparation of flour from whole banana fruit may be an alternative to the use of this food crop for the production of spaghetti with a high amount of indigestible carbohydrates.

\section{Acknowledgements}

We would like to thank and acknowledge the financial support provided by SIP, COFAA, and EDI-Instituto Politécnico Nacional.

\section{REFERENCES}

[1] J. P. Gutiérrez, J. Rivera-Dommarco, T. Shamah-Levy, S. Villalpando-Hernández, A. Franco, L. Cuevas-Nasu, M. Romero-Martínez and M. Hernández-Ávila, "Encuesta Nacional de Salud y Nutrición 2012. Resultados Nacionales,” Instituto Nacional de Salud Pública, Cuernavaca, 2012.

[2] C. M. Tudorica, V. Kuri and C. S. Brennan, "Nutritional and Physicochemical Characteristics of Dietary Fiber Enriched Pasta," Journal of Agricultural and Food Chemistry, Vol. 50, No. 2, 2002, pp. 347-356. http://dx.doi.org/10.1021/jf0106953

[3] H. Araya, N. Pak, G. Vera and M. Alviña, "Digestion Rate of Legume Carbohydrates and Glycemic Index of
Legume-Based Meals," International Journal of Food Science and Nutrition, Vol. 54, No. 2, 2003, pp. 119-126. http://dx.doi.org/10.1080/0963748031000084061

[4] R. C. Kill and K. Turnbull, “Tecnología de la Elaboración de Pasta y Sémola,” Acribia, Madrid, 2004.

[5] Y. H. Zhao, F. A. Manthey, S. K. Chang, H. Hou and S. H. Yuan, "Quality Characteristics of Spaghetti as Affected by Green and Yellow Pea, Lentil, and Chickpea Flours,” Journal of Food Science, Vol. 70, No. 5, 2005, pp. 371-380.

[6] P. Rayas-Duarte, C. M. Mock and L. D. Satterlee, “Quality of Spaghetti Containing Buckwheat, Amaranth, and Lupin Flours," Cereal Chemistry, Vol. 73, No. 3, 1996, pp. 381-387.

[7] M. Granito, A. Torres and Y. M. Guerra, "Desarrollo y Evaluación de Una Pasta a Base de Trigo, Maíz, Yuca y Frijol,” Interciencia, Vol. 28, No. 3, 2003, pp. 372-379.

[8] R. G. Hernández-Nava, J. De J. Berrios, J. Pan, P. Osorio-Díaz and L. A. Bello-Pérez, "Development and Characterization of Spaghetti with High Resistant Starch Content Supplemented with Banana Starch,” Food Science and Technology International, Vol. 15, No. 1, 2009, pp. 73-75. http://dx.doi.org/10.1177/1082013208102379

[9] M. C. Bustos, G. T. Perez and A. E. León, "Sensory and Nutritional Attributes of Fibre-Enriched Pasta," LWT Food Science and Technology, Vol. 44, No. 6, 2011, pp. 1429-1434. http://dx.doi.org/10.1016/j.lwt.2011.02.002

[10] J. G. Krishnan, R. Menon, G. Padmaja, M. S. Sajeev and S. N. Moorthy, "Evaluation of Nutritional and PhysicMechanicaal Characteristics of Dietary Fiber-Enriched Sweet Potato Pasta," European Food Research and Technology, Vol. 234, No. 3, 2012, pp. 467-476. http://dx.doi.org/10.1007/s00217-011-1657-8

[11] N. Faisant, A. Buléon, P. Colonna, C. Molis, S. Lartigue, J. P. Galmiche and M. Champ, "Digestion of Raw Banana Starch in the Small Intestine of Healthy Humans: Structural Features of Resistant Starch," British Journal of Nutrition, Vol. 73, No. 1, 1995, pp. 111-123. http://dx.doi.org/10.1079/BJN19950013

[12] R. A. González-Soto, E. Agama-Acevedo, J. SolorzaFeria, R. Rendón-Villalobos and L. A. Bello-Pérez, "Resistant Starch Made from Banana Starch by Autoclaving and Debranching," Starch/Stärke, Vol. 56, No. 10, 2004, pp. 495-499. http://dx.doi.org/10.1002/star.200400283

[13] S. L. Rodriguez-Ambriz, J. J. Islas-Hernández, E. AgamaAcevedo, J. Tovar and L. A. Bello-Pérez, "Characterization of a Fibre-Rich Powder Prepared by Liquefaction of 
Unripe Banana Flour,” Food Chemistry, Vol. 107, No. 4, 2008, pp. 1515-1521. http://dx.doi.org/10.1016/j.foodchem.2007.10.007

[14] E. Juárez-García, E. Agama-Acevedo, S. G. SáyagoAyerdi, S. L. Rodríguez-Ambríz and L. A. Bello-Pérez, "Composition, Digestibility and Application in Breadmaking of Banana Flour,” Plant Foods Human and Nutrition, Vol. 61, No. 3, 2006, pp. 131-137. http://dx.doi.org/10.1007/s11130-006-0020-x

[15] M. Ovando-Martínez, S. G. Sáyago-Ayerdi, E. AgamaAcevedo, I. Goñi and L. A. Bello-Pérez, "Unripe Banana Flour as an Ingredient to Increase the Undigestible Carbohydrates of Pasta," Food Chemistry, Vol. 113, No. 1, 2009, pp. 121-126. http://dx.doi.org/10.1016/j.foodchem.2008.07.035

[16] A. Aguirre-Cruz, A. Alvarez-Castillo, H. Yee-Madeira and L. A. Bello-Perez, "Production of Fiber-Rich Powder by the Acid Treatment of Unripe Banana Flour,” Journal of Application Polymers Science, Vol. 109, No. 1, 2008, pp. 382-387. http://dx.doi.org/10.1002/app.28095

[17] AACC, “Approved Methods of the AACC," American Association of Cereal Chemists, St. Paul, 2000.

[18] I. Goñi, L. García-Diz, E. Mañas and F. Saura-Calixto, "Analysis of Resistant Starch: A Method for Foods and Food Products,” Food Chemistry, Vol. 56, No. 4, 1996, pp. 445-449. http://dx.doi.org/10.1016/0308-8146(95)00222-7

[19] F. Saura-Calixto, A. García-Alonso, I. Goñi and L. Bravo, "In Vitro Determination of the Indigestible Fraction in Foods: An Alternative to Dietary Fiber Analysis," Journal of Agriculture and Food Chemistry, Vol. 48, No. 8, 2000, pp. 3342-3347. http://dx.doi.org/10.1021/jf0000373

[20] H. N. Englyst and J. H. Cummings, "Improved Method for the Measurement of Dietary Fibre as Non-Starch Polysaccharides in Plant Foods,” Journal of AOAC, Vol. 71, No. 4, 1988, pp. 808-814.

[21] I. Goñi and C. Valentín-Gamazo, “Chickpea Flour Ingredient Slows Glycemic Response to Pasta in Healthy Volunteers," Food Chemistry, Vol. 81, No. 4, 2003, pp. 511515. http://dx.doi.org/10.1016/S0308-8146(02)00480-6

[22] A. Torres, J. Frias, M. Granito and C. Vidal-Valverde, "Germinated Cajanus cajan Seeds as Ingredients in Pasta Products: Chemical, Biological and Sensory Evaluation," Food Chemistry, Vol. 101, No. 1, 2006, pp. 202-211. http://dx.doi.org/10.1016/j.foodchem.2006.01.018

[23] A. Torres, J. Frias, M. Granito, M. Guerra and C. Vidal-
Valverde, “Chemical Biological and Sensory Evaluation of Pasta Products Supplemented with $\alpha$-Galactoside-Free Lupin Flours," Journal of the Science of Food and Agriculture, Vol. 87, No. 1, 2007, pp. 74-81. http://dx.doi.org/10.1002/jsfa.2673

[24] F. A. Manthey and A. L. Schorno, "Physical and Cooking Quality of Spaghetti Made from Whole Wheat Durum,” Cereal Chemistry, Vol. 79, No. 4, 2002, pp. 504-510. http://dx.doi.org/10.1094/CCHEM.2002.79.4.504

[25] C. S. Brennan and C. M. Tudorica, "Fresh Pasta Quality as Affected by Enrichment of Nonstarch Polysaccharides," Journal of Food Science, Vol. 72, No. 9, 2007, pp. 659665. http://dx.doi.org/10.1111/j.1750-3841.2007.00541.x

[26] J. W. Dick and V. L. Youngs, "Evaluation of Durum Wheat Semolina and Pasta in the United States," In: G Fabriani and C. Lintas, Eds., Durum Wheat, Chemistry and Technology, AACC Press, St. Paul, 1998, pp. 238248.

[27] Y. Bahnassey and K. Khan, "Fortification of Spaghetti with Edible Legumes. II. Rheological, Processing, and Quality Evaluation Studies,” Cereal Chemistry, Vol. 63, No. 2, 1986, pp. 216-219.

[28] C. Antognelli, "The Manufacture and Applications of Pasta as a Food and as a Food Ingredient: A Review," Journal of Food Technology, Vol. 15, No. 1, 1980, pp. 9-29.

[29] Y. Pomeranz, "Modern Cereal Science and Technology," VCH Publishers, New York, 1987.

[30] A. J. Rosenthal, "Food Texture: Measurement and Perception,” Aspen Publishers Inc., Gaithersburg, 1999.

[31] E. Agama-Acevedo, J. J. Islas-Hernandez, P. Osorio-Díaz, R. Rendon-Villalobos, R. G. Utrilla-Coello, O. Angulo and L. A. Bello-Perez, "Pasta with Unripe Banana Flour: Physical, Texture, and Preference Study," Journal of Food Science, Vol. 74, No. 6, 2009, pp. S263-S267. http://dx.doi.org/10.1111/j.1750-3841.2009.01215.x

[32] P. Osorio-Díaz, A. Aguilar-Sandoval, E. Agama-Acevedo, R. Rendón-Villalobos, J. Tovar and L. A. Bello-Pérez, "Composite Durum Wheat Flour/Plantain Starch White Salted Noodless: Proximal Composition, Starch Digestibility, and Indigestible Fraction Content," Cereal Chemistry, Vol. 85, No. 3, 2008, pp. 339-343. http://dx.doi.org/10.1094/CCHEM-85-3-0339

[33] S. Hendrich, "Battling Obesity with Resistant Starch," Food Technology, Vol. 64, No. 3, 2010, pp. 22-30. 